\title{
Lebanese Students' Attitudes toward English: An Exploratory Study
}

\author{
Ghada M. Chehimi \\ Correspondence: Ghada M. Chehimi, Lebanese University, Faculty of Letters and Human Sciences, Beirut, Lebanon.
}

Received: April 6, 2021

Accepted: May 18, 2021

Online Published: May 19, 2021

doi:10.5430/elr.v10n2p20

URL: https://doi.org/10.5430/elr.v10n2p20

\begin{abstract}
This is a study of high school students' attitudes toward the English language in Lebanon. The purpose of this research is to assess the extent of use of English inside and outside the schools taking into consideration the attitude towards the language. Two schools were selected, one upper middle class and one lower middle class. This selection of different social classes aims at finding whether a student's socio- economical background affects his/ her attitude toward the English language.

The sample of respondents returned 52 questionnaires from the two schools. Although this sample was a modest one, it highlighted the differences in attitudes towards the English language, but these attitudes did not relate much to the socioeconomic class as much as personal preferences. However, what was salient in this research is how students from the lower middle class were more inclined to use English to raise their social status and both groups agreed that English is essential to their progress in life.
\end{abstract}

Keywords: high school students, English language, attitude, Lebanon

\section{Introduction}

Lebanon has always been a country where people had the privilege to be bilingual or multilingual. And the general social understanding is that the more languages people know or speak, the more prestige they get (Kinzler, Shutts \& Spelke, 2012; Spencer, Clegg, \& Stackhouse, 2013) and the better the professional advancement chances they have.

The majority of the Lebanese people are bilingual since World War I. Then, French was the second language and most Lebanese students had to learn it because Lebanon was under the French mandate (Kurani, 1936). Therefore, schools in Lebanon were using French as a second language after Arabic (Zouain, 1994). But as the status of the English language started rising in the world after World War II, the French language started its decline in Lebanon and many schools had to shift to teaching English as a second language or add English as a third language (Bacha \& Bahous, 2011).

English with its global spread has put many people and especially young students under so much pressure (Makewa, Role \& Tuguta, 2013) because many believe that in order to achieve and become successful, a person has to master the English language (The English Language Center-ELC, 2013). Such pressure has created a variety of reactions and attitudes toward English ranging from acceptance to refusal. Consequently, many high school students find it challenging to learn and to use the language to fit an upper social classification. Therefore, observing high school students' behaviors and language use in different social contexts was the reason behind this study of attitudes.

This paper is divided into five sections. The first section provided an introduction and background for the research followed by the literature review in section two and research methodology in section three. Section four is about the discussion of results and findings and finally, section five provides a closure with a conclusion and recommendations.

\section{Literature Review}

\subsection{Learning and Attitude}

Learning a language is closely related to the attitudes towards languages (Starks \& Paltridge, 1996, p. 218; Ahmad, 2015, p. 6). The Longman Dictionary of Applied Linguistics and Language Teaching (2002) defines language attitudes as follows: "the attitudes which speakers of different languages or language varieties have towards each other's languages or to their own language. Expressions of positive or negative feelings towards a language may reflect impressions of linguistic difficulty or simplicity, ease or difficulty of learning, degree of importance, elegance, social status, etc. Attitudes towards a language may also show what people feel about the speakers of that language" (Richards, Schmidt, Platt, \& Schmidt, 2002, p. 286). 
Several researchers contend that the learners' attitude and motivation are stimuli for language learning. For example, Donitsa-Schmidt, Inbar, \& Shohamy (2004) maintain that different aspects of language attitudes have also been studied such as the relation between attitudes and motivation. Two decades earlier, Gardner (1985, p.10) sees attitudes as components of motivation in language learning. According to him, "motivation ... refers to the combination of effort plus desire to achieve the goal of learning the language plus favorable attitudes toward learning the language" (p. 10). He believes the "motivation to learn a foreign language is determined by basic predispositions and personality characteristics such as the learner's attitudes towards foreign people in general, and the target group and language in particular, motives for learning, and generalized attitudes" (ibid). Later, Wenden (1991) stated that attitudes include three components: cognitive which involves beliefs or perceptions about the objects or situations related to the attitude; evaluative which means that the objects or situations related to the attitude may generate like or dislike; and behavioral which states that certain attitudes tend to prompt learners to adopt particular learning behaviors. In brief, "attitudes are learned motivations, valued beliefs, evaluations, or what one believes is acceptable', and favorable attitudes tend to influence language learning" (p. 52). The aforementioned is congruent with Burden's (2004) statement, "As attitude is arguably a component of motivation, favourable attitudes towards learning combined with effort produce learning goals" (p. 21). On the other hand, Dornyei and Ushioda (2011) posit that "although sociocultural theory is essentially a theory of learning, it has recently begun to inform approaches to understanding motivation as a socially mediated and culturally situated phenomenon" (p. 33). More recently, Tanni (2015) asserts that "It has been identified that learner's attitudes toward a target language and its speakers as well as the use of that language play a central role in determining levels of success for the learning and acquisition of that language" (p. 139).

In the present day, Doğan \& Tuncer (2020) summarize that "among the individual differences, which are considered to affect academic achievement in a foreign language, the variables most emphasized in the relevant literature are affective (motivation, attitude, self-confidence, self-efficacy, anxiety ... etc.) and cognitive (intelligence, language ability, learning strategies, cognitive / metacognitive awareness... etc.) ones" (p. 83). Further, the authors add, "As to the role of attitudes in the Second Language Acquisition (SLA) field, they have long been researched as a determinant of language learning motivation and achievement" (ibid). Though a large number of research studies have been conducted in the western world, very few were conducted in the Middle East considering differences of social status among learners. To the knowledge of the researcher, none has been conducted in Lebanon. Therefore, this paper is considered one of the few in the region. Consequently, it aims to assess the extent of use of English inside and outside selected schools considering the attitude towards the language. What is particular about this work is that the schools have been selected to represent two different social classes in Lebanon. Therefore, the following research questions are proposed:

1) Are Lebanese high school students' attitudes toward English an outcome of their socio-economic status?

2) Is there is a significant difference between high school students' attitudes towards English in an upper middle private school and a lower middle private school?

\subsection{Learning, Attitude and Context}

Bushenhofen (1998) claims that attitudes towards language cannot be viewed as stable. Attitudes are strongly responsive to contextual conditions, especially changing conditions which occur during several significant transitions including the move from high school to university, during the course of students' university careers as well as after the significant transition from university to work. On the other hand, Vogt \& Oliver (1998), in their survey for Kuwait medical students' attitudes toward English-based medical and science curriculum in comparison to other Arab students, they assert that the medical students seem to have a positive attitude and favored studying English because it is the common scientific language regardless of the grade they received. Additionally, the students' attitudes and motivational factors are consistent with their Arab counterparts in other countries and university settings. In another research about social attitudes of students towards teaching English at high schools in Gaziantep, Turkey, Bagceci (2005) reports that teaching English is not in accordance with the requirements and demands of the students. Moreover, in the context of high school students' attitudes towards learning or teaching English, Diab (2006) has compared Lebanese English as Foreign Language (EFL) university students' beliefs about learning different target languages, namely, English, and French, and she has investigated within-group variation in these students' beliefs. Her findings reveal that the said students hold a variety of beliefs about learning English and French, many of which seem to be related to the political and socio-cultural context of foreign language education in Lebanon. In addition, most students revealed strong instrumental motivations for learning English and agreed that it is more 
important to learn English than French. Recently, Shah (2017) endorses and stresses in his work, "the growing trend towards an integration of motivation and context in a dynamic way" (p. 3). The aforementioned literature does not address social differences observed by attending schools of different sociocultural values, leading to the proposition of the following research questions:

1) Do Lebanese high school students consider English important for their future careers?

2) Do Lebanese high school students speak English in public to demonstrate an upper class belonging?

3) Do Lebanese high school students speak English in class because of class policies?

\subsection{Research Hypotheses}

Based on the research questions proposed, the following hypotheses are tested to assess the statistical significance of the objectives sought in the questions:

1) Lebanese high school students' attitudes toward English are basically an outcome of their socio-economic status.

2) Lebanese high school students consider English important for their future careers.

3) Lebanese high school students speak English in public to demonstrate an upper class belonging.

4) Lebanese high school students speak English in class because of class policies.

5) There is a significant difference between high school students' attitudes towards English in an upper middle private school and a lower middle private school.

\subsection{Scope of the Study}

The research findings contained in this paper provide both qualitative and quantitative information to assist the researcher to draw up indicators in relation to this issue. The research focuses on the assessment, on an exploratory basis, of the attitude towards English language by a conveniently selected Lebanese student sample. Two schools were selected on the basis of the social class that their students belong to namely, middle-upper class versus lower-middle class.

\section{Research Methodology}

This research follows a positivism philosophy. Hejase \& Hejase (2013) contend that research philosophy is the first issue to be taken into consideration for the researcher. "Positivism is when the researcher assumes the role of an objective analyst, is independent, and neither affects nor is affected by the subject of the research" (Hejase \& Hejase, 2013, p. 77). Moreover, this study uses a mix method, that is, a quantitative and qualitative research methods. Having this research based mainly on quantitative research method, then the approach followed is deductive. "A deductive approach is useful if the general aim was to test a previous theory in a different situation or to compare categories at different time periods" (Elo \& Helvi, 2008, p. 107). On the other hand, a qualitative methodology is used to validate the primary data by following an inductive approach via interviews. The interviews were semi-structured, and a sample of students was given the freedom to elaborate on some issues when they felt they needed to do so. In fact, primary data is needed in this research to assess the selected Lebanese students' levels of awareness about the topic of English language importance in their life. Such data is necessary to support the development and design of English language teaching policies in the different educational institutions so that to minimize the stress and unhealthy feelings that may result from such topic misunderstanding. Furthermore, this paper deals with an unstructured problem and the researcher wants to gain more knowledge about its characteristics. Consequently, research design is exploratory (Hejase \& Hejase 2013, p. 110) which is carried out to collect primary data needed to shed light on the subject of this research. Currently, to the researcher's knowledge, there are no published figures detailing the comparative opinions of Lebanese students to the concept of attitude towards English language.

\subsection{Research Design}

This research was carried out in Lebanon in two private high schools as the target study. The first high school was from the upper-middle socio-economical class (Rawdah) and the second from a lower-middle socio-economical class (Adventist). These two schools were selected for their reputation in society and that reputation characterizes the social classification of each school. Table 1 offers a brief overview about each school. 
Table 1. Sample Schools

\begin{tabular}{|c|c|c|}
\hline & \multicolumn{2}{|c|}{ School } \\
\hline & Rawdah High School & Adventist School Mouseitbeh \\
\hline Type & Upper-middle socio-economical class & Lower-middle socio-economical class \\
\hline Foundation year & 1961 & 1929 \\
\hline Ownership & $\begin{array}{l}\text { Privately owned } \\
\text { coeducational day school }\end{array}$ & $\begin{array}{l}\text { Philanthropic: Seventh-day Adventist } \\
\text { mission school. Private pre-K-12 } \\
\text { coeducational day school }\end{array}$ \\
\hline $\begin{array}{l}\text { Languages } \\
\text { taught }\end{array}$ & $\begin{array}{l}\text { Language of instruction is English. } \\
\text { Arabic is taught at all levels }\end{array}$ & $\begin{array}{l}\text { Language of instruction is English. } \\
\text { Arabic is taught at all levels }\end{array}$ \\
\hline Nomination & Secular, multicultural community & Secular, multicultural community \\
\hline Size & Around 1,600 students all levels & Around 600 students all levels \\
\hline
\end{tabular}

Sources: https://rhs.edu.lb/ \& https://mass.edu.lb

Two classes were selected from these schools, one from each. The class was a grade12 Economics and Sociology section. Students in each class filled 26 questionnaires. Questionnaires were developed after an extensive literature review on the topic, focus groups with high school students and conversations with academic colleagues. The researcher formulated most of the questions, but the questions in the scale section of the questionnaire (from number 1- 11) were adopted from Karahan Firdev (2007) then tailored to the Lebanese context. The researcher administered the distribution and the filling of the questionnaires with the assistance of the classroom teacher after obtaining the rightful permission of both the school administration and the teacher. Questionnaires were filled after the researcher distributed consent forms to students to agree on participating in this research. Students showed interest and the majority participated and their help was greatly appreciated.

The qualitative method used to collect more data for this research by conducting students' interviews. Two students from each school were selected randomly from the class list and they were also asked for their willingness to participate. The interview was semi-structured, and students were given the freedom to elaborate on some issues when they felt they needed to do so. The researcher used a tape recorder with the permission of the students and took few notes when the students were answering questions.

\subsection{Data Analysis}

Data analysis for this research used the Statistical Product and Service Solutions SPSS version 25.0, an IBM product since 2009 (Hejase \& Hejase, 2013). Analysis included descriptive statistics by sorting and organizing data in frequency and percentage tables. Moreover, one way analysis of variance (ANOVA) and T-test were used to identify the difference between the schools. And finally, students' attitudes towards English and the relation between socio-economic status and attitudes were examined through Chi Square test of independence. Furthermore, Cramer's $\mathrm{V}$ test of the strength of the relationship and Mann Whitney U Test to test differences are used.

\section{Results and Discussion}

\subsection{Descriptive Analysis}

\subsubsection{Demographics}

$38.5 \%$ are males and $61.5 \%$ are females. The mean average age for both genders is 17 years.

Respondents belong equally to each high school with $50 \%$ belong to the Adventist School with medium to low social class students and $50 \%$ belong to the Rawdah High School with medium to high social class students. 94.2\% said that Arabic is their first language versus 3.8\% who claim that English is their first language. 65.4\% learned their English as a second language in preschool. Finally, 78.8\% of the respondents relate their learning of the English language to boost their future education abroad, to have better jobs in the future, and to broaden their horizons.

\subsubsection{Personal Opinions}

Table 2 shows that the majority of the respondents reflect through their responses that they are excited about learning English because it is a necessity in culture (90.40\% agree), feel they are proficient (92.30\% agree), feel comfortable speaking English in class and in public (75.0\% agree), and feel at ease with English in other topics (75.0\% agree). Furthermore, respondents believe that teachers play an important role in class $(90.40 \%$ agree on the teachers' role to diffuse positive attitude among students) and that all Lebanese should learn English (73.10\% agree). 
Table 2. Personal Opinions

\begin{tabular}{cl|cc}
\hline \multicolumn{1}{c|}{ Statement } & Yes, \% & No, \% \\
\hline 1. & English necessity in culture & 90.4 & 9.6 \\
2. & English Proficiency & 92.3 & 7.7 \\
3. & Comfortably speaking English in class & 75.0 & 25.0 \\
4. & Comfortably speaking English in public & 75.0 & 21.2 \\
5. & Difficulty in learning English & 7.7 & 92.3 \\
6. & Easiness to learn other subjects in English & 78.8 & 21.2 \\
7. & Teachers play an important role in giving a positive attitude toward & 90.4 & 9.6 \\
& English language classes & & \\
8. & All Lebanese should learn English & 73.1 & 26.9 \\
\hline 9. & Teachers should be allowed to use Arabic in English classes & 15.4 & 84.6 \\
\hline
\end{tabular}

\subsubsection{Cross-tabulation "Students' Attitude" with "High School"}

A cross-tabulation was performed between students' attitude towards English language and the high school they belong to. Such an analysis shall provide a good differentiation between the students' attitudes versus the culture adopted within their schools. Table 3 shows all pertaining results. For the analysis, the researcher has grouped "strongly agree and agree" statements within one variable denoting agreement (A) and similarly for the disagreement dimension (D).

Table 3. Cross-tabulation "attitude" versus "School Identity"

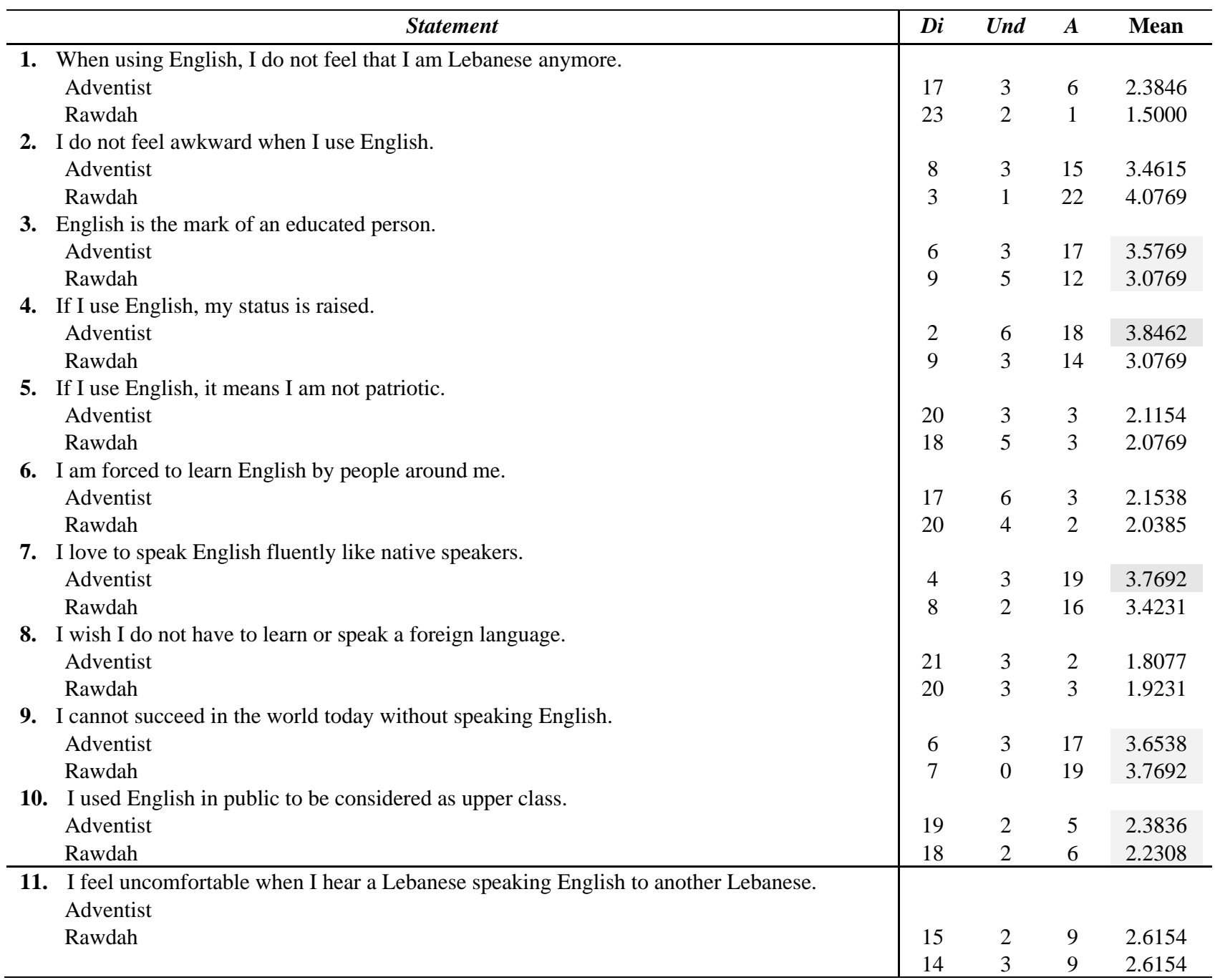


Tables 3 shows that students from the Adventist high school demonstrate more concern about learning English as shown from items 3,4,7, 9 and 10. The most salient reasons are: achieving higher education status (item 3) and social status (item 4). Moreover, the Adventist students would like to achieve native speakers' proficiency (item 7). Both groups agreed that their success in the world dependents on learning English (item 9) however, both groups disagree that using English in pubic shall have the purpose to increase their social status (item 10).

Knowing that the Adventist students belong to the middle-lower social class the results demonstrate higher eagerness and motivation to grow in status to secure a better future in Lebanon. In fact, the World Resources Institute (WRI, 2008, pp. 28-29) contend that, "learning is central to resilience and adaptability over time. Indeed, social resilience is not about avoiding change but about gaining the tools to survive and reorganize when change is inevitable" (pp. 28-29) — in other words, "learning to adapt" (Folke et al., 2002, p. 7). Moreover, Lebanese boast about social status and the general population wishes higher social status privileges (personal communication with Prof. Talal Atrissi, Lebanese expert Sociologist).

When students were asked their opinion about speaking English in class or using English outside school, the Rawdah students were more motivated to do so as the comparison of means show: 3.1538 versus 2.4000 (speaking English in class) and 3.3462 versus 2.4000 (speaking English outside school) the second scores are for Rawdah high school with 3 denoting sometimes and 2 denoting frequently. It looks like the Rawdah students are already comfortable with their status and use English to show that. As a matter of fact, Doğan \& Tuncer (2020) supported the notion that performance is driven by self-confidence and self-efficacy.

\subsubsection{Univariate Statistical Analysis}

Having selected two independent groups of students belonging to two different social categories, the following statistical tests were performed: Chi square, Mann Whitney U and t-test analysis.

\section{A. Chi Square test of independence (cross-table analysis) Results}

The purpose is to test the relationship between speaking English inside or outside the classroom and the social status manifested by the type of high school respondents belong to.

Table 4. Frequency in speaking English inside the class * High School

\section{Cross tabulation}

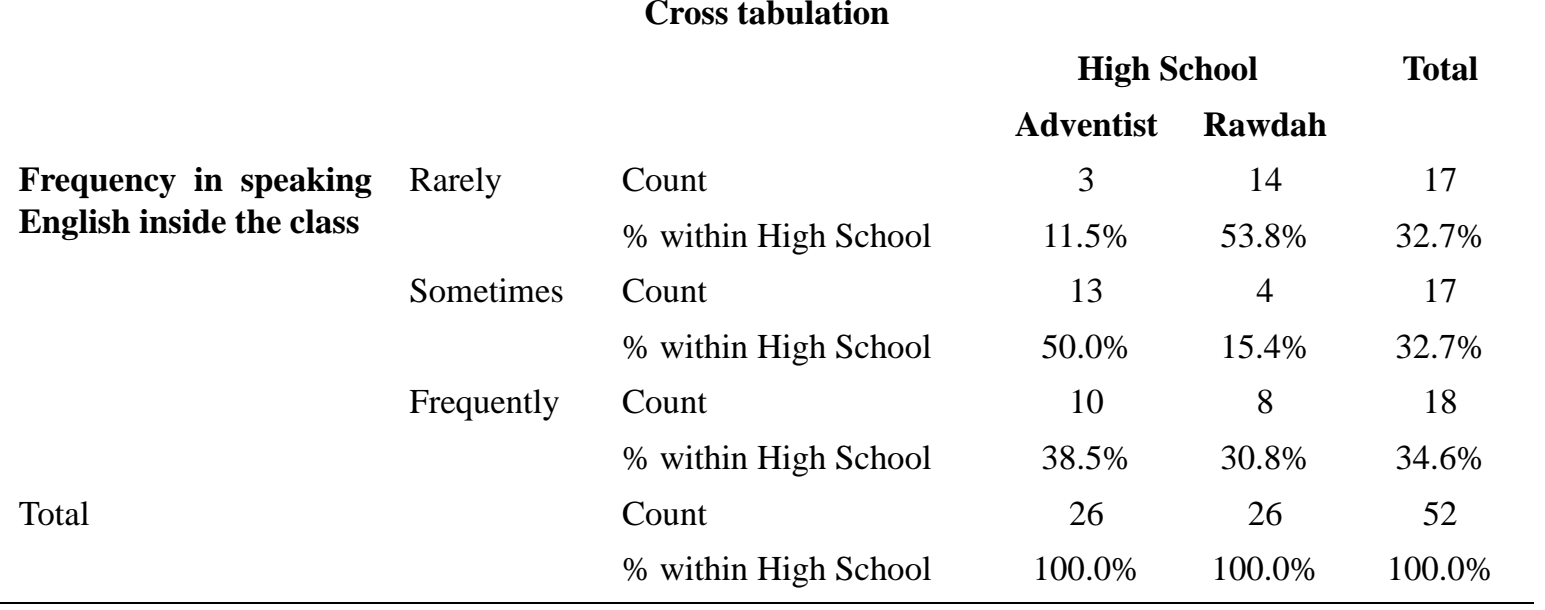

Table 5. Frequency in speaking English inside the class * High School

\begin{tabular}{lccc}
\hline & Chi-Square Tests & \\
& Value & Df & Asymp. Sig. (2-sided) \\
Pearson Chi-Square & $12.105^{\mathrm{a}}$ & 2 & .002 \\
Likelihood Ratio & 12.962 & 2 & .002 \\
Linear-by-Linear Association & 4.738 & 1 & .029 \\
N of Valid Cases & 52 & & \\
a. 0 cells (.0\%) have expected count less than 5. The minimum expected count is 8.50.
\end{tabular}


Table 4 shows that the Pearson Chi-Square value is 12.105 with a significance level of $0.002<0.05$ [no cells have fewer than 5 cases], means that the null hypothesis that there is no significant relationship, is rejected. Therefore, there is a significant relationship between the high school and speaking English inside the classroom. Moreover, Table 4 shows that the Adventist students thus appear to be significantly more inclined to speak English inside the classroom with $88.5 \%$ (sometimes and frequently) versus $46.2 \%$ (sometimes and frequently) for Rawdah high school.

Table 6. Frequency in speaking English inside the class * High School

\begin{tabular}{llcc}
\hline & Symmetric Measures & \\
Nominal by Nominal & Phi & Value & Approx. Sig. \\
& Cramer's V & .482 & .002 \\
N of Valid Cases & & .482 & .002 \\
& & 52 &
\end{tabular}

The Cramer's V in Table 6 tells us something about the strength of the significance relationship. A value of zero indicates no relationship; a value of one indicates a perfect relationship. The value of 0.482 obtained indicates that the significant relationship is moderately strong (with significance $0.002<0.05$ ). Furthermore, at the bottom of Table 5 , a check is shown in footnote ' $a$ '. Because there are no cells in the example $(=0 \%)$ which have an expected frequency lower than five (the recommended is that this percentage should be lower than 20\%), and the minimal expected frequency is 8.50 (this should be at least 1), the conditions have been met here such that there is no problem in the case.

A similar analysis is conducted for the case of students speaking English outside the classroom. Results demonstrate that the corresponding Pearson Chi-Square number 2.743 with a significance level of $0.254>0.05$ means that the null hypothesis that there is no significant relationship, is accepted. Therefore, there is no significant relationship between the high school and speaking English outside the classroom. However, data shows that the Adventist students thus appear to be lightly more inclined to speak English outside the classroom with $80.7 \%$ (sometimes and frequently) versus $65.3 \%$ (sometimes and frequently) for Rawdah high school. Here, results fit Diab's (2006) arguments about the socio-cultural context of foreign language education in Lebanon. Finally, the corresponding Cramer's V indicates a weak significance relationship (significance value $0.254>0.05$ ).

\section{B. Mann Whitney U Test}

Mann Whitney U tests the null hypothesis that both groups (Adventist versus Rawdah students) have, on average, the same attitude toward language. All scores for both groups are combined and an overall ranking is calculated. The mean rank for each group is next calculated and both mean ranks are compared. The null hypothesis is that both mean rankings are equal. 
Table 7. Mann-Whitney U Test Statistics (Significance Compared to critical p- value $=0.05$ )

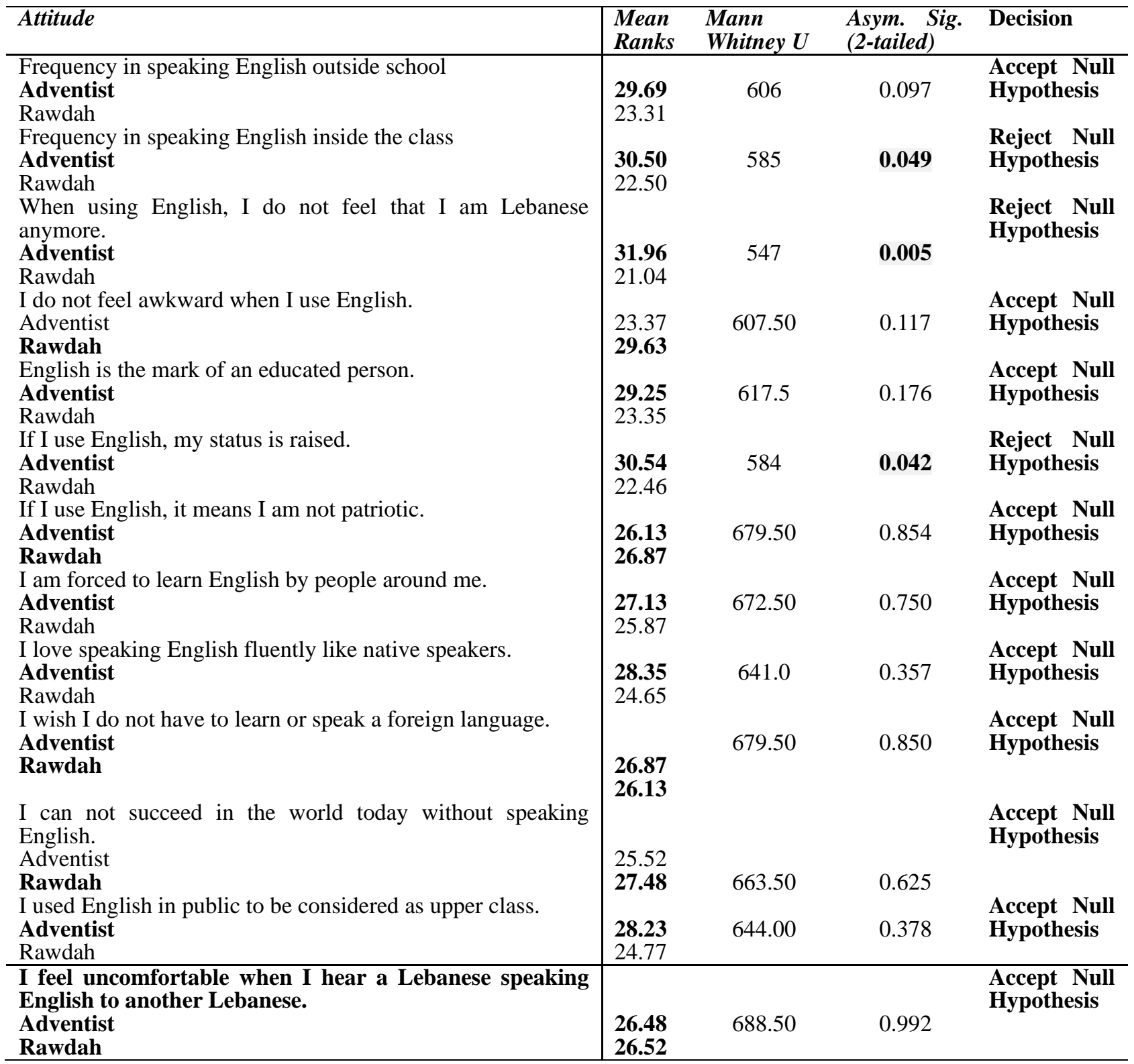

Table 7 shows that the Rawdah students have a lower ranking in points 2, 3 and 6 compared to the Adventist students [shaded]. A lower ranking for the Rawdah would mean that on average the school has a higher preference for the defined attitudes (speaking English inside the classroom, speaking English and national belonging and the issue of social status). However, we need to look at the relevant Mann Whitney U calculated Value, its associated z-Value and most important the p-value (Asymptotic Significance). The three cases 2, 3 and 6 have p-values $<0.05$ (shown in bold). In these cases, we may reject the null hypothesis that both schools show same attitude towards English. Therefore, the ranking of the above -mentioned attitudes are significantly different for both schools' respondents. It happens that the Adventist students put more effort to speak the language in class, seek with higher fervor a better status, and still possess a strong national feeling. The Adventist students reflect the attitudes of the middle-lower social class which naturally struggle harder for higher status in Lebanon in comparison to the Rawdah students who already possess a higher social status. Indeed, as stressed by Richards, Schmidt, Platt, \& Schmidt (2002, p. 286).

All remaining attitudes show a Mann Whitney $U$ calculated values with p-values higher than the critical p-value of 0.05 . The null hypotheses are not rejected, and the ranking of attitudes are not significantly different for Adventist and Rawdah respondents. However, we can observe on average the Adventist respondents are more sensitive to the different attitudes and they practice effectively what they feel. 


\section{T-test Analysis}

Next, the researcher would like to know whether there is a difference in attitude preferences between the Adventist and Rawdah respondents. So, independent observations are accounted for and one must find out if the group variances are equal. The "Levene's test of equality of variances" is first performed.

The Null hypothesis, $\mathrm{H}_{\mathrm{o}}$ : both populations have the same variances.

Group statistics were performed. If the Null hypothesis cannot be rejected, the t-value from the output must be read in the case of equal variances; in the other case, the t-value must be read from the output of unequal variances.

Results show that three attitudes: (When using English, I do not feel that I am Lebanese anymore), (I do not feel awkward when I use English), and (If I use English my status is raised) demonstrate that the Null hypothesis may be rejected $(0.030,0.035$ and 0.005 < critical p-value 0.05$)$. Their correspondent statistical significance attributed to the t-test outputs for unequal variances assumed of the first and third statements are 0.009 and 0.017 reflecting that there is significant difference between the Adventist and Rawdah respondents with respect national belonging and the interest to raise social status. The Rawdah students are more enthusiastic to achieve better status in their lives. The aforementioned is asserted by Bushenhofen (1998) who relates attitudes towards language as strongly responsive to the transition and the move from high school to university. In fact, Rawdah's students are trained to perform highly in English language in order to secure acceptance in the highest tier universities of Lebanon. As for the second attitude the p-value of the t-test for equal variances not assumed is $0.094>0.05$ which indicates that there is no significant preference on the issue of not feeling awkward when using English (on the average both groups feel equally). All other dimensions reflect that the null hypothesis of equal variances may not be rejected (Levene's significance value $>0.05$ ). The $t$-tests outputs for equal variances assumed are all $>0.05$ which reflects the fact that both schools show no significant preferences for the attitudes.

\subsubsection{The Interviews}

The researcher found that qualitative analysis is of additional value to this research. Interviews were carried out to further identify on one-to-one basis with students' issues that relate to the formal survey. Four students were selected randomly from both schools and were asked to meet with the researcher at a coffee shop where students their age would feel comfortable in such place. Each student was given a different appointment. Each interview took 10- 15 minutes maximum.

They were asked if they prefer to speak Arabic or English and they all had no problem answering in English. The researcher told them that they can use either language as long as they feel comfortable.

Therefore, the interviews were carried out in English and in few instances, students asked for clarifications and they ended up mixing Arabic and English in the interview. The questions were mainly developed around the attitudes toward English and how they perceive the status of the English language in Lebanon and around the world.

The following questions were asked:

1) Do you feel comfortable speaking English with me?

2) Do you speak English with your friends? When and where?

3) When you hear people speaking English in public places in Lebanon, do you feel awkward? Why?

4) How do you feel when you hear your friends communicating in English? Explain

5) As a young man or woman, do you consider yourself more important as a speaker of English than if you were not?

6) Does using a foreign language in Lebanon mean that you belong to an upper class? If yes, why and if no, why?

7) Do you think that young people your age try very hard to fit into an upper class or are they comfortable where they are?

8) Is English an important language in the world? Explain

These were the main questions asked. Though few times, the researcher had to restate, explain, or elaborate the question. In a semi-structured interview setting, both the researcher and the interviewees were comfortable, and it was carried out with a more informal approach. 


\section{Results of the Interviews}

School A: Rawdah High school (upper-middle class)

School B: Adventist school (lower middle class)

For question 1, all students felt comfortable speaking to the researcher.

Student A1 "I like the topic, a fact that eases my tensions for this interview"

Student A2 "I am acquainted with interviews, since we conduct at school informal and interactive conversation sessions"

Student B1 and B2 "we are excited for being selected for this interview, and we are ready to participate"

For question 2, the students from school A answered more affirmatively about speaking English with their friends in school settings and outside in public. Their responses were as follows:

A1 "I feel privileged when speaking to one another in English, and I feel certain security when I address my friends in English especially when being among unknown people"

A2 "I am accustomed to speak fully in English"

Whereas students from school B said they do not speak it much in school or out in public.

B1 "I feel obliged to speak English for the simple fact to practice in school but I do that few times in public, because I feel people look at me strangely"

B2 "I try to address my friends in English when we are in public to show off as many do"

For question 3, all replied negatively. And they considered speaking English in public in Lebanon something very normal.

A2 "I simply feel I am being myself in public when speaking in English, so why I should feel awkward?"

B1 "Obliging myself to speak in English strengthened my self confidence among other people in public"

For question 4, students from school A said they do not feel anything because it is a normal thing.

A1 "Speaking English is just a habit for me"

A2 "I even speak English at home, with relatives and friends"

But students from school B had different opinions, one said

B1 "It gives me (male) a negative feeling because my friends insist to use Arabic" and the other student B2 said, "Hearing friends speaking English in public in not something I like because I think they are trying to show off".

For question 5, all the students affirmed that English is important, but it does not make them feel important as speakers. However, they all also stressed on the advantage of speaking English and its importance for their future.

A1 "Our teachers always emphasize the importance of speaking two languages, and they say English is universal. I agree but I do not feel this affects my social status"

A2 "I want to study abroad and work abroad, my very good English is my ticket for such objective"

B1 "I stress on my efforts to strengthen my English because of my future plans, though I do not agree it affects my personality as an English speaker".

B2 "I agree with my friend about our future endeavors, English is fundamental. Also, in Lebanon most of the students speak English or other language, some of them they show off and feel important, I do not agree"

For question 6, students from school A said that speaking English does not make one as an upper-class person but it is a privilege to speak more than one language. And speaking English is essential for success.

A1 "Lebanon is a multilingual country. I always heard that Lebanese are privileged because of the ease to speak English, French, Armenian or other language. I do not agree that my social status will go higher because of my English"

A2 "I belong to the higher-social class and I do not need a Language to be so. However, for me, having a strong English language opens the future for me especially if I will work for a foreign firm"

Students from school B said that many people try to speak English to show that they are from the upper-class society even if they are not. And they had a criticism about this phenomenon in Lebanon and its effect on young people 
regardless of their place in society.

B1 "I do not care to show off like many others do in the community. Lebanon is a highly show off country because people care about appearance and try to behave as rich even if they are not, and this is sad"

B2 "Sometimes I try to go along when others show off by speaking English to each other, but later I feel I am not myself, so I stop doing that. However, this does not mean I do not care about my English proficiency, because I needed to build ma career for the future and it is needed for my college years"

For question 7, all the students agreed that young people like them are not satisfied or comfortable with their social status, and all want to do something whether through speaking a foreign language or anything else to rise on the societal scale.

A1 "In Lebanon, the society adds pressure on us to behave like upper-class to fit in certain groups. My proficiency in English helps. Being a student in an upper-high school, facilitates this endeavor for me"

A2 "As I mentioned earlier, I am from an upper-class, and my English sustains my status. I will use my family contacts (network) to improve my status further by taking advantage of better job opportunities even while I am studying high school and later in my college years"

For question 8, all the students from both schools answered positively about the importance of the English language and one of the students said that if someone from the same generation does not know or speak English, he/she will not reach anywhere in their lives.

A1 "I will use my English proficiency to score higher in my SAT scores and therefore I will join a high status University especially that I can afford it. Later on, English is known as the Business language, and this is something I want to pursue. It is a matter to assure a better future in a country with less job opportunities"

A2 "I mentioned earlier that I talk to my friends, relatives and others in English. I will continue doing this to assure better future"

B1 "I know for fact that English is important, and even if I am not convinced that it will affect my social status, I am convinced that if someone from the same generation does not know or speak English, he/she will not reach anywhere in their lives"

B2 "I am interested to build a career in the future, and therefore I am working hard to continuously improve my English skills"

Also, they all stressed on the universal spread of the language and they all mentioned globalization and the internet. And what attracted the researcher's attention was one of the students from school B's comment on language and power and he spoke so well on the power a language can have over people and when people become like slaves to the language because without it, they cannot do anything, and they will not be able to progress.

A1 "English is universal, look at the USA and its power in all fields"

A2 "We are living in an interconnected planet via the Internet, and as far as I know English is a powerful tool to communicate"

B1 "Although my friends try to influence me to speak in my mother language, I am trying hard to strengthen my skills because I believe that if I am highly proficient I will gain power over others. I will be able to join privileged groups and that will assure me better future. Also, I am convinced that we belong to the digital young generation, English will help me and others to manipulate technological devices and consequently will raise my influence over others"

B2 "I agree with my friend about the internet community, and I also believe English is a must to be a successful citizen of the virtual world and the global work force"

\section{Conclusion}

As a conclusion, the research hypotheses were statistically tested. The null hypotheses were not rejected indicating that both high school respondents have similar preferences toward the attitudes. However, three statements showed that the Adventist School respondents were keen to improve their social status by speaking English.

1) Lebanese high school students' attitudes toward English are basically an outcome of their socio-economic status.

2) Lebanese high school students consider English important for their future careers.

3) They speak English in public to demonstrate an upper class belonging. 
4) They speak English in class because of class policies; this is evident in the responses of both schools when speaking English outside school where no policies are enforced.

Language comes with power, prestige, and position (Kinzler, Shutts \& Spelke, 2012; Spencer, Clegg, \& Stackhouse, 2013). When learned and used with proficiency, language provides its users a platform which can be social, educational, and economical. Lebanon, as a multilingual country (Thonhauser, 2000), thrives on foreign language learning and acquisition among its citizens. Therefore, it is the norm to see Lebanese people using different languages and, on many occasions, code switching, and code mixing are used (Bacha \& Bahous, 2011). Its is also important to note that being multilingual and feeling comfortable speaking any of these languages is sometimes considered a social status determiner in the Lebanese society. Accordingly, in this research study, the Adventist School students, who belong to the lower middle class, showed more passion when they talked about English language use which indicates an apparent difference with the Rawdah High School students who belong to the upper middle class. The situation in Lebanon as related to social classes behavior is supported by the Rawdah HS respondents who felt at ease in expressing their attitude toward English and manifested passive feelings when social status was mentioned. This is typical for the upper middle class who already belong to it.

This research covered a small sample to highlight the issue of students' attitudes toward the English language. The aforementioned is considered a limitation for the study and implying that findings may not be generalized, though beneficial as an eye opener for further investigation considering larger samples and involving more schools. However, it is recommended that future research should be carried out by choosing a larger sample and including schools that belong to several social classes including the upper-class, the upper middle class and to compare with a lower middle-class school which will possibly demonstrate statistically significant results. The significance of this research is in its approach to offer comparative analysis between social classes and language use in Lebanon, a fact that enriches the scarce secondary records and research carried out on this subject using the same methodology. Results are important for teachers, school administrators and government officials so that when curriculum upgrades are considered, the social identities and geographical locations of schools become a factor that help in motivating students toward better learning of language. In fact, Schweisfurth (2019) asserts that "if we combine the right basis of learner centered education (LCE) with the evidence concerning teaching that stimulates learning, we can create a flexible set of principles (rather than prescriptions) that might be helpful in improving practice everywhere" (Para 4). Moreover, Zak (2013), stressed the human side of management of any institution (applied in this case to school administrators) by repeating Drucker's words, "It is the relationship with people, the development of mutual confidence, the identification of people, and the creation of a community" (Hejase, 2020). The aforementioned is capable to enrich motivation and attitude towards learning of languages.

\section{References}

Ahmed, S. (2015). Attitudes towards English Language Learning among EFL Learners at UMSKAL. Journal of Education and Practice, 6(18), 6-16. https://files.eric.ed.gov/fulltext/EJ1079681.pdf

Bacha, N. N., \& Bahous, R. (2011). Foreign Language Education in Lebanon: A Context of Cultural and Curricular Complexities. Journal of Language Teaching and Research, 2(6), 1320-1328. https://doi.org/10.4304/jltr.2.6.1320-1328

Bağçeci, B. (2005). Social Attitudes of Students towards Teaching English at High Schools in Gaziantep, Turkey. Biotechnology \& Biotechnological Equipment, 19(1), 201-204. https://doi.org/10.1080/13102818.2005.10817182

Burden, P. (2004). An Examination of Attitude Change towards the Use of Japanese in a University English 'Conversation' Class. Regional Language Center Journal, 35(1), 21-36. https://doi.org/10.1177/003368820403500104

Bushenhofen, P. (1998). English language attitudes of final-year high school and first-year university students in Papua New Guinea. Asian Journal of English Language Teaching, 8, 93-116.

Diab, R. (1996). University students' beliefs about learning English and French in Lebanon. System, 34(1), 80-96. https://doi.org/10.1016/j.system.2005.06.014

Doğan, Y., \& Tuncer, M. (2020). The Role of attitudes in Foreign Language Learning. In Yunus Dogan, Editor (Ed.), Academic Studies in Foreign Language Education (pp. 83-99). Lyon, France: Livre de Lyon.

Donitsa-Schmidt, S., Inbar, O., \& Shohamy, E. (2004). The effects of teaching spoken Arabic on students' attitudes and motivation in Israel. Modern Language Journal, 88, 217-228.

https://doi.org/10.1111/j.0026-7902.2004.00226.x 
Dornyei, Z., \& Ushioda, E. (2011). Teaching and researching motivation. Harlow, England: Longman

Elo, S., \& Helvi, K. (2008). The qualitative content analysis process. Journal of Advanced Nursing, 62(1), $107-115$. https://doi.org/10.1111/j.1365-2648.2007.04569.x

Folke, C., Carpenter, S., Elmqvist, T., Gunderson, L., Holling, C. S., Walker, B., ... Svedin, U. (2002, September). Resilience and Sustainable Development: Building Adaptive Capacity in a World of Transformation. Journal of the Human Environment, 31(5), 437-40. https://doi.org/10.1579/0044-7447-31.5.437

Gardner, R. C. (1985). Social psychology and second language learning: The role of attitudes and motivation. London: Edward Arnold.

Hejase, A. J., \& Hejase, H. J. (2013). Research Methods: A Practical Approach for Business Students (2nd ed.). Philadelphia, PA, USA: Masadir Inc.

Hejase, H. J. (2020). The Mutual Routes of Measurement and Management. Journal of Economics and Economic Education Research, 21(6), 1-3. https://doi.org/10.13140/RG.2.2.21234.32964

Karahan, F. (2007). Language attitudes of Turkish students towards the English language and its use in Turkish context. Journal of Arts and Sciences, 7, 73-87.

Kinzler, K. D., Shutts, K., \& Spelke, E. S. (2012). Language-based social preferences among children in South Africa. Language learning and development, 8(3), 215-232. https://doi.org/10.1080/15475441.2011.583611

Kurani, H. (1936). Education in Territories under French Mandate. The Open Court, 1936(2), 79-93. https://opensiuc.lib.siu.edu/ocj/vol1936/iss2/2

Makewa, L. N., Role, E., \& Tuguta, E. (2013). Students' Perceived Level of English Proficiency in Secondary Schools in Dodoma, Tanzania. International Journal of Instruction, 6(2), 35-52.

Richards, J. C., Schmidt, R., Platt, H., \& Schmidt, M. (2002). Longman Dictionary of Language Teaching and Applied Linguistics (3rd ed.). Harlow, United Kingdom: Pearson Education Limited/Longman.

Shah, M. (2017). The Contextual Motivational Conditions for L2 Pedagogy: A Case Study from the Arabian Gulf. Australian Journal of Teacher Education, 42(10). https://doi.org/10.14221/ajte.2017v42n10.1

Spencer, S., Clegg, J., \& Stackhouse, J. (2013). Language, social class and education: listening to adolescents' perceptions. Language and Education, 27(2), 129-143. https://doi.org/10.1080/09500782.2012.760585

Tanni, Z. A. I. (2015). Attitudes toward English among Al-Quds Open University Students in Tulkarm Branch. World Journal of Education, 5(3), 139-147. https://doi.org/10.5430/wje.v5n3p139

The English Language Center-ELC. (2013, September 30). 4 reasons why learning English is so important [Blog]. Retrieved March 21, 2021, from https://www.elc-schools.com/blog/4-reasons-why-learning-english-is-so-important/

Thonhauser, I. (2000). Multilingualism Education in Lebanon: 'Arabinglizi' and Other Challenges of Multilingualism. Mediterranean Journal of Educational Studies, 6(1), 49-61.

Vogt, C., \& Oliver, D. (1998, April). Students' attitudes toward English and an English based curriculum.' Kuwait University, Faculty of Medicine. Research report no 143. Retrieved February 27, 2021, from https://files.eric.ed.gov/fulltext/ED422714.pdf

Wenden, A. L. (1991). Learner strategies for learner autonomy. London: Prentice Hall.

World Resources Institute (WRI). (2008). World Resources 2008: Roots of Resilience-Growing the Wealth of the Poor. World Resources Institute (WRI) in collaboration with United Nations Development Programme, United Nations Environment Programme, and World Bank. Washington, DC: WRI. Retrieved May 12, 2021, from http://pdf.wri.org/world_resources_2008_roots_of_resilience.pdf

Zak, P. (2013). Measurement myopia. Drucker Institute. Retrieved March 21, 2021, from https://www.drucker.institute/thedx/measurement-myopia/

Zouain, G. (1994). Lebanon: Systems of education. In T. Husen and T. N. Postlethwaite (Eds.). The international encyclopedia of education (pp. 3349-3356). Oxford: Pergamon.

\section{Copyrights}

Copyright for this article is retained by the author(s), with first publication rights granted to the journal.

This is an open-access article distributed under the terms and conditions of the Creative Commons Attribution license (http://creativecommons.org/licenses/by/4.0/). 